\title{
Economics
}

\section{Polarization of Wealth, Saving and Terminable Currency}

\author{
Ma Quanxiu', Mou Yong ${ }^{2}$ \\ ${ }^{1}$ Li Wang School District, Zhongwei, China \\ ${ }^{2}$ Anhui University of Science and Technology, Huainan, China \\ Email address: \\ 420908084@qq.com (Ma Quanxiu), 103295327@qq.com (Mou Yong)
}

\section{To cite this article:}

Ma Quanxiu, Mou Yong. Polarization of Wealth, Saving and Terminable Currency. Economics. Vol. 8, No. 3, 2019, pp. 88-97. doi: 10.11648/j.eco.20190803.11

Received: June 23, 2019; Accepted: July 12, 2019; Published: July 30, 2019

\begin{abstract}
Extreme polarization of wealth, a prominent issue occurring in the long human history characterized by the rule of emperor, remains a serious problem in a very few nations. The modern times have seen how the worsening rich-poor divide led to the breaking out of the two world wars and a series of social problems. In some sense, rich-poor divide results in the deterioration of human nature, and is the source of all kinds of social problems. This study provides a definition of polarization of wealth, conducts an analysis of how people's continuous saving behavior contributes to the increase in income disparity, and suggests that currency, as a universal equivalent, should be given a certain time limit, so as to ensure a check on people's constant saving conduct, prevent the limitless amassing of wealth and help solve the issue of wealth polarization.
\end{abstract}

Keywords: Polarization of Wealth, Operation Mode of the New Economy, Saving, Terminable Currency

\section{Introduction}

The issue of gap of wealth is a global problem which is undergoing serious deterioration, and is estimated to keep worsening. According to a study conducted by Picktty (2014), today top $10 \%$ of the Americans have $50 \%$ of the total wealth of America, with the top 1\% population in possession of $20 \%$ of all the fortune. For most of the nations, the problem of income disparity calls for urgent solutions.

Today, the global economy is faced with wealth gap, inflation, unemployment and other challenges. In this context, it is of great significance to examine the causes of these problems and find the solutions.

The purpose of this paper is to illustrate that wealth gap is the root cause of all economic issues, and that the world can become a utopia where each one is well employed and happy with their life, provided that the problem of wealth gap is solved.

First, the paper will give a definition of wealth gap, followed by an analysis of its causes; then it will explore the impacts of the gap on all social issues; after that, an ideal economic operation model will be discussed; at last, the operational mechanism for terminable currency, the key to the successful running of ideal economy, will be described.

\section{Polarization of Wealth}

\subsection{Traditional Definition}

Researchers at home and abroad have conducted a lot of studies about wealth gap, inflation, unemployment and other issues, as is shown in the abundant literatures. Generally, the consensus is that human capital gap will lead to income gap, and different jobs as well as birth environments also contribute to income disparity. As a result, both income gap and wage gap contribute to wealth gap. This paper holds that wealth gap is different from wealth polarization, in that the former is none but the product of the latter, which is a process rather than a state, as seen in the following discussion.

Researchers differ greatly on the relationships between wealth gap and the high rate of saving. Some take the high rate of saving as the cause, some hold that the gap is the cause, and others tend to think that they interact as both cause and effect. According to a study carried out by Peng Mengxia [1], et al (2011), there is a steady and long-term relationship between the rural saving rate and urban-rural income gap, namely, the higher the rate, the larger the gap. Jin Ye [2] et al (2011) find out that income gap has a stronger inhibitory effect on the consumption of low-income families or young couples, and a positive influence on educational investment, a likely 
consideration to promote one's social status. Yang Miaoshu [3] (2011) points out that increase in the urban-rural income gap would make it harder for the young couples to support their parents and grandparents, which will in turn further enlarge the income gap. Wang Xiaolu [4] (2007) argues that over savings and under-consumption have a negative impact on the effective demand at the macroeconomic level, leading to the growing dependence of economic growth on investment and export, resulting in excessive rapid growth of demand for energy and raw materials, excessive production capacity and excess liquidity. In short, the author holds that extreme income gap is the cause of high saving rate. Yang Xufei [5] (2009) also attributes the high saving rate to extreme income gap. Cheng Ying [6] (2007) argues that high saving rate is the main cause for the increasing income gap, which has long made consumption at a low level and brought a "high saving and high investment" vicious circle to the economy. Therefore, the primary need is to take effective steps to bring down the saving rate on the part of the government and the state-owned economic sectors. Han Xiaoyan [7] (2010) indicates that high saving rate has made it difficult for firms to gain access to financing, exposed banks to higher risks, discouraged residents' consumption, among other negative impacts on economy and worsen income gap.

On the other hand, Song Yunxing [8] (2015) shows a reserved attitude towards the relations between income gap and saving. In his empirical analysis based on OECD national panel data (1991-2010), it is revealed that Gini coefficient exerts a positive, steady and long-term effect on the national saving rate.

All the findings achieved by the above researchers have helped shape the direction for this study.

\subsection{Definition of Wealth Polarization}

Wealth polarization refers to the process in which income gap occurs among people, which is measured in money, or currency. In other words, wealth polarization means that society divides in terms of people's disposable money.

What decides the disposable money lies in three factors: power, wealth and education. That is why wealth polarization is examined under the framework of political power, economic wealth and academic education in this paper.

\subsubsection{Wealth Polarization Due to Political Power}

Concentration of political power leads to this kind of wealth polarization in that people have a bottomless desire for power, which in turn maximizes the one's power. It is due to the maximization of one's power that authoritarian countries have given rise to the pyramid structure of power and cult for authority.

This kind of wealth polarization can be further classified into three categories.

One is the inheritance of the ancient power concentration.

The inheritance of the ancient power concentration features the family-based concentration and handing over of power, which was the main approach adopted in the old times when despotism and kingship prevailed, as was the case with China from Yu age to the late Qing dynasty, as well as North Korea, Cuba, and Saudi Arabia and other absolutist countries in our time. Privilege is the feature of this kind of political power, and it results in wealth concentration, legal despotism, planned economy and extreme wealth polarization.

The second is the contemporary handing over of concentrated power.

The modern transfer of concentrated power mainly features the handing over of party-based concentrated power through in-service appointment or voting election, as is the practice in one-party dictatorships, such as former Soviet and China. Such kind of power concentration always results in centralization of power, formalization of legal democracy, authoritarian and semi- authoritarian of economy operation, extreme or excessive wealth polarization. In a commodity economy, its authoritarian and semi- authoritarian nature is due to the fact that those in power have intervened and influenced the commodity economy by participating in it. In this case, the internal differentiation of the assets of economy has been created, or the absolutization and relative absolutization of the wealth polarization has been created.

The third is the modern handing over of divided power.

Modern power differentiation is based on the idea that absolute power inevitably leads to absolute corruption, and adopts the transfer of power through political campaign among parties, as is the case with modern European countries and the United States. It brings about legal democracy, market economy, wealth polarization within an acceptable range. In short, this system, featuring power differentiation and power $\mathrm{s}$ restriction, poses a restriction on people's bottomless desire for power, shifts the exercise of power to the society, and establishes a supervision and restraint system for the usage of power.

In the absence of checks and balances of power, power may be abused for the gaining of individual wealth. And the concentration of power will facilitate the concentration of fortune and will destroy the normal order of commodity economy, the issue of wealth polarization will worsen. Meanwhile, it must be pointed out that power is forever an intangible wealth, in that it can directly produce fortune-or currency. It is due to this function of power that people are willing to buy power at a certain price so as to produce more wealth.

\subsubsection{Wealth Polarization in Terms of Economic Wealth}

This kind of wealth polarization can also be divided into three types.

One is the convergent polarization.

Convergent polarization refers to business corporations that amass fortune by the maximization of profits through the prices setting and brand promotion to appeal to consumers' preference, or through the direct control and monopoly of economic resources. Further, income gap is enlarged through the distribution of profits among firms and staff of the same companies, and among firms, staffs of the same companies and other laborers.

The second is the succeeded polarization of wealth. 
Succeeded polarization of wealth refers to the owners of fortune who hand over their wealth to their younger generations, thus leading to a more serious wealth polarization in the next generations. It directly leads to the worsening polarization of the coming generations.

The third is the intensive wealth polarization.

Intensive wealth polarization refers to the departments of the state organs, such as administrative department, department of education, health sector, banks, that have direct control over monetary wealth, resources, transportation, water conservancy and other key economic sectors, and that enjoy privileges in the distribution of fortune, thus leading to the income gap between their staff and the common workers.

\subsubsection{Wealth Polarization Due to Knowledge and Education}

This kind of polarization is classified into three types, and is highly relevant with the youth.

One is the differences in the levels of knowledge and culture which is produced by personal willingness, or the gap of knowledge and culture due to the lack of opportunities arising from the neglect of education when young.

The second is wealth polarization due to birth circumstances. Those born to disadvantaged families tend to have less education opportunities, which in turn put them at a disadvantage over their peers.

The third is the polarization due to social conditions. The imbalanced allocation of education resources, especially in terms of faculty resources, plus the difference in teachers' competency, cultural knowledge and morality, has contributed to the division of the students into the skilled and the unskilled.

This kind of wealth polarization constitutes the main cause of that due to knowledge and education gap, because the division of the a society into the rich and poor will consequently result in a series of social issues, such as social pressure, life stress, extreme wealth and extreme poverty, which will also have a serious effect on the adults' cognitive perspective, mentality and psychology, and all these will shape their kids in terms of knowledge and education, resulting in wealth polarization.

\subsection{What Makes Wealth Polarization Worse}

Qur'an 9:34 [9], "O ye who believe! there are indeed many among the priests and anchorites, who in Falsehood devour the substance of men and hinder (them) from the way of Allah. And there are those who bury gold and silver and spend it not in the way of Allah. announce unto them a most grievous penalty. Qur'an 9:35 [10], On the Day when heat will be produced out of that (wealth) in the fire of Hell, and with it will be branded their foreheads, their flanks, and their backs, their flanks, and their backs.- "This is the (treasure) which ye buried for yourselves: taste ye, then, the (treasures) ye buried!

According to this teaching, boarding of property is a sin, and it follows that the rich is committing crime if they continue to amass fortune. For, as mentioned before, saving is the root cause of deteriorating polarization of wealth. And savings here means the total fortune under the direct disposal of the producers, including savings of enterprises and citizens in banks, as well as the currency in circulation held by citizens and enterprises, and people's physical assets in its broadest sense. And producers refer to all participants in the commodity economy, with enterprises and self-employed as the core.

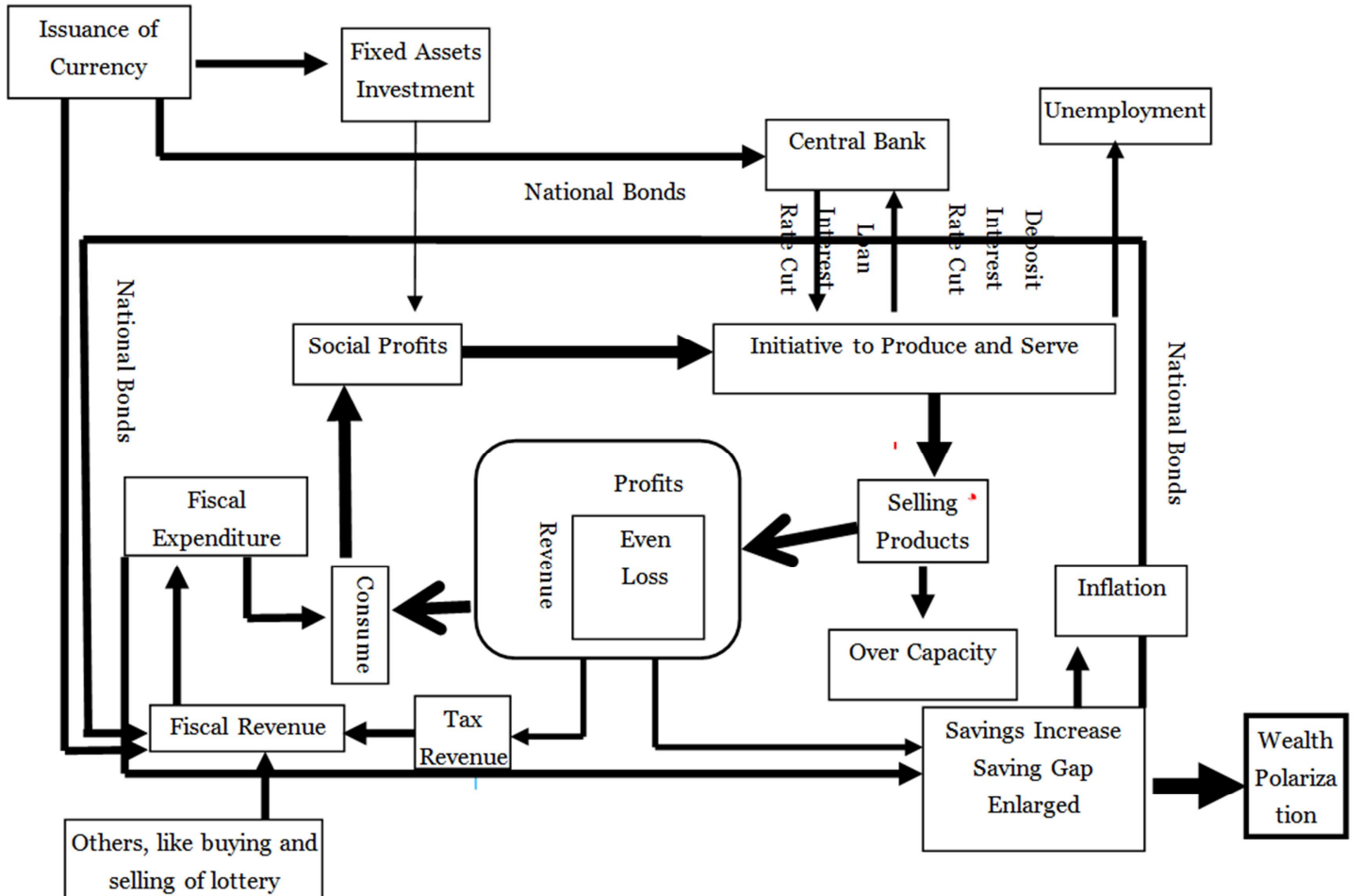

Figure 1. Economic Operation Model Leading to Deteriorating Polarization of Wealth. 
Figure 1 shows that the social profits mostly come from government's investment in fixed assets, and after going through the operation process of commodity economy, such profits end up in the bank accounts of the rich and powerful. Since social profits are none other but the balance of the monetary amount of income minus that of expenditure under a nominal currency value. It actually means the part that the value of producers' income exceeds that of their investment. Value here means the benefits which products' performance bring upon people's production and life, while social profits include the difference between total consumption and total production costs, as well as government's investment in fixed assets.

Condition 1: An equation is formed in which the total amount of money in circulation in a commodity economy amounts to the total amount of cash in circulation plus the total amount of money out of a commodity economy. Savings refer to the total wealth under producers' direct disposal, including the cash savings of enterprises and citizens in banks, as well as currency in circulation held by citizens and enterprises, and the property of citizens.

(government's total investment in fixed assets in the past + government's total fiscal expenditure in the past) in circulation in the commodity economy=[money \& quasi-money supply (M2)+(the current year foreign exchange reserves - the current year balance of the debt)+total tax revenue in the past +cash amount kept by citizens] out of circulation in the commodity economy.

Condition 2: Data in Condition 1 are listed in the following figure.

Table 1. Government's Annual Fixed Assets Investment from 2000 to 2009.

\begin{tabular}{llllllllll}
\hline $\mathbf{2 0 0 0}$ & $\mathbf{2 0 0 1}$ & $\mathbf{2 0 0 2}$ & $\mathbf{2 0 0 3}$ & $\mathbf{2 0 0 4}$ & $\mathbf{2 0 0 5}$ & $\mathbf{2 0 0 6}$ & $\mathbf{2 0 0 7}$ & $\mathbf{2 0 0 8}$ & $\mathbf{2 0 0 9}$ \\
\hline 32917.70 & 37213.50 & 43499.90 & 55566.60 & 70477.40 & 88773.60 & 109998.20 & 137323.90 & 172828.40 & 224598.80 \\
\hline
\end{tabular}

(Source: National Bureau of Statistics of China. Unit: 100 million Yuan)

Table 2. Government's Annual Fiscal Expenditure from 2000 to 2009

\begin{tabular}{llllllllll}
\hline $\mathbf{2 0 0 0}$ & $\mathbf{2 0 0 1}$ & $\mathbf{2 0 0 2}$ & $\mathbf{2 0 0 3}$ & $\mathbf{2 0 0 4}$ & $\mathbf{2 0 0 5}$ & $\mathbf{2 0 0 6}$ & $\mathbf{2 0 0 7}$ & $\mathbf{2 0 0 8}$ & $\mathbf{2 0 0 9}$ \\
\hline 15886.50 & 18902.58 & 22053.15 & 24649.95 & 28486.89 & 33930.28 & 40422.73 & 49781.35 & 62592.66 & 76299.93 \\
\hline
\end{tabular}

(Source: National Bureau of Statistics of China. Unit: 100 million Yuan)

Table 3. Money \& Quasi-money Supply (M2) (Unit: 100 million Yuan).

\begin{tabular}{lllll}
\hline $\mathbf{2 0 0 5}$ & $\mathbf{2 0 0 6}$ & $\mathbf{2 0 0 7}$ & $\mathbf{2 0 0 8}$ & $\mathbf{2 0 0 9}$ \\
\hline 298755.70 & 345577.90 & 403442.21 & 475166.60 & 610224.50 \\
\hline
\end{tabular}

Table 4. China's Annual Tax Revenue from 2000 to 2009.

\begin{tabular}{llllllllll}
\hline $\mathbf{2 0 0 0}$ & $\mathbf{2 0 0 1}$ & $\mathbf{2 0 0 2}$ & $\mathbf{2 0 0 3}$ & $\mathbf{2 0 0 4}$ & $\mathbf{2 0 0 5}$ & $\mathbf{2 0 0 6}$ & $\mathbf{2 0 0 7}$ & $\mathbf{2 0 0 8}$ & $\mathbf{2 0 0 9}$ \\
\hline 12325 & 14963 & 16851 & 19843 & 24144 & 28575 & 35035 & 46632 & 55010 & 59515 \\
\hline
\end{tabular}

(Source: National Bureau of Statistics of China. Unit: 100 million Yuan)

China's foreign exchange reserves in 2009 reached $\$ 2,399.152$ billion*6.82=163,622.16 Yuan; its outstanding external debt in the same year amounted to $\$ 428.646$ billion $* 6.82=29,233.65$ Yuan (State Administration of Foreign Exchange).

(2000-2009 government's total fixed asset investment 97319.8 billion Yuan+2000-2009 government's total fiscal expenditure 37,300.6 billion Yuan, making up the total in circulation $=[2009$ total deposit balance $61,022.45$ billion Yuan $+2000-2009$ China's tax revenue 31,289.3 billion Yuan+ (2009 China's foreign exchange reserves \$163,622.16 -2009 China's outstanding external debt 2,923.365billion Yuan)+2009 cash kept by citizens] out of circulation in the commodity economy.

Conclusion 1: 2009 cash kept by citizens = $(973198+373006) \quad$ (hundred million)
Yuan-(610224.50+312893+134388.51) (hundred million) Yuan=1346204 (hundred million) Yuan -1057506 (hundred million) Yuan $=288698$ (hundred million) Yuan.

Conclusion 2: In a commodity economy the currency comes primarily from two sources: Fixed asset investment and bank. And more currencies settle down in the saving accounts of citizens and enterprises. Meanwhile, while citizens' savings increase, the different borrowing power among citizens and the unequal revenue model also enlarge the savings gap, resulting in the widening of polarization of wealth.

In short, the government has to increase its investment in fixed assets to offset the inflow of currency into savings accounts. The different borrowing power of citizens and their unequal income model also widen the savings gap along with the increase in the total savings, resulting in the worsening of wealth polarization. 


\section{Effects of Wealth Polarization}

\subsection{Wealth Polarization Is the Root Cause of Inflation}

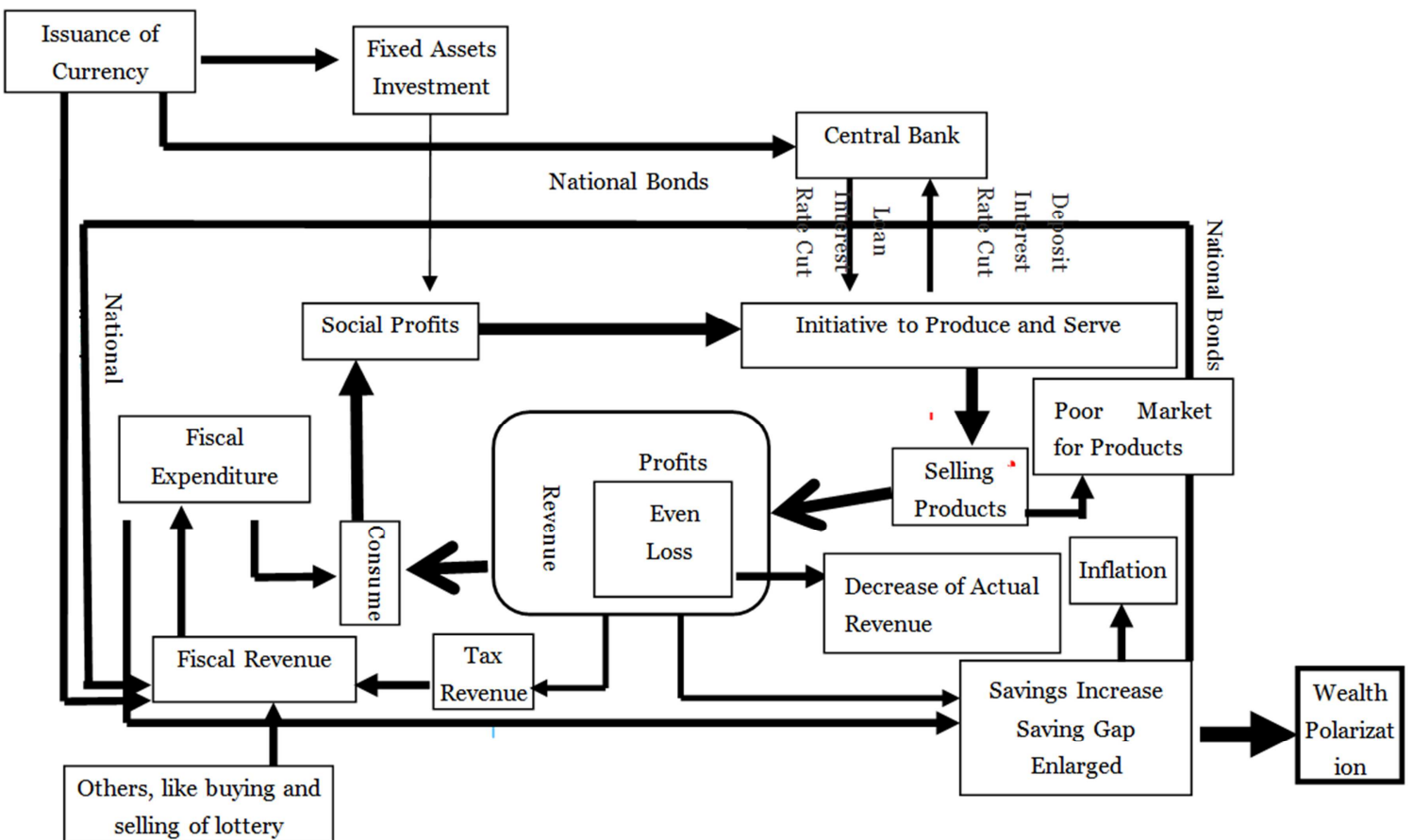

Figure 2. Inflation.

Inflation is a sustained increase in the general price level of goods and services in an economy over a period of time, but in essence, it is due to the differentiation of people's purchasing power arising from the wealth polarization. The negative effect of a mild inflation is that the people of low income cannot afford to buy the necessary articles, while in a virulent inflation, not only does the currency lose its function as a universal equivalent, people at the bottom of a society are in a state of extreme poverty, but the commodity economy cannot operate normally.

Wealth polarization of citizens is the root cause of inflation.

Hypothesis 1: For simplicity, suppose there are only three producers in a commodity economy, $\mathrm{A}, \mathrm{B}$, and $\mathrm{C}$, each having one Yuan currency, further suppose that it costs one Yuan to produce one piece of bread, and that at the beginning each has only one Yuan as capital with one piece of bread to consume. Lastly, suppose the ratio of income among $\mathrm{A}, \mathrm{B}$, and $\mathrm{C}$ is $1: 2: 3$.

Result 1: The first consumption produces 3 Yuan currency, and after that the money kept by $\mathrm{A}$ is $3 * 1 / 6=0.5$ Yuan; $\mathrm{B}$, $3 * 2 / 6=1$ Yuan; and C, $3 * 3 / 6=1.5$ Yuan, with no bread left.

Hypothesis 2: An input of 6 Yuan into the commodity economy produces 6 pieces of bread, producing currency amounting to 9 Yuan, which, divided by 6 (pieces of bread), means that each piece of bread is worth 1.5 Yuan.

Hypothesis 3: An input of 6 Yuan into the economy, with 1 Yuan kept by A, 2 by B, and 3 by C (with the same income ratio).

Result 2: Now A spends 1.5 Yuan to buy one piece of bread, or one piece of bread costs him 1.5 Yuan, so in his case currency is devaluated, or there is inflation; B can spend 3 Yuan to buy two pieces of bread, or one piece of bread costs him 1.5 Yuan, so in his case there is 1.5 Yuan left, worth one piece of bread, which means a currency devaluation, but without inflation; $\mathrm{C}$ can spend 4.5 Yuan to buy three pieces of bread, or one piece of bread costs him 1.5 Yuan, so in his case three Yuan is saved, meaning a devaluated currency, but without inflation.

The second consumption produces currency amounting to: $1.5+1.5+1.5=4.5$ Yuan. And the profits arising from this 4.5 Yuan of consumption will distribute to the saving accounts of $\mathrm{A}, \mathrm{B}$ and $\mathrm{C}$ in the ratio as follows: $1 / 6 * 4.5=0.747,2 / 6 * 4.5=1.5$, and $3 / 6 * 4.5=2.25$ (Yuan).

The second consumption brings to A such money as the 0.75 Yuan of profit; for B, the money is the unused 1.5 Yuan plus the 1.5 Yuan of profit, or 3 Yuan; for C, the money is unused 3 Yuan plus the 2.25 Yuan profit, or 5.25 Yuan. And the second consumption leaves 3 pieces of bread unconsumed.

Hypothesis 4: An input of 6 Yuan into the economy to produce 6 pieces of bread, which produces 15 Yuan of currency in the economy, with 6 pieces of bread available (the 3 pieces of bread left unconsumed in the last case is not included given the consideration of time), so each piece of bread is worth 2.5 Yuan.

Hypothesis 5: An input of 6 Yuan with 1 Yuan kept by A, 2 by $\mathrm{B}$ and 3 by $\mathrm{C}$ (with the same income ratio).

Result 3: A cannot buy one piece of bread with 1.75 Yuan, which leads to currency devaluation and growing inflation; B can buy two pieces of bread with 5 Yuan, despite of currency devaluation, for there is not inflation. And $\mathrm{C}$ can use 8.25 
Yuan to buy 3.3 pieces of bread, and there is currency devaluation but no inflation.

Conclusion: Result 1, 2 and 3 all show that constant fixed asset investment under a certain proportion of rich and poor leads to the shrinking of A's fortune, but the growing of C's wealth. Similarly, the same is true of macro economy, that is, constant fixed asset investment plus unequal income model leads to a widening savings gap and worsening wealth polarization, resulting in currency devaluation. In other words, inflation has more negative impact on the producers who suffers losses.

\subsection{Wealth Polarization Is the Root Cause of Unemployment}

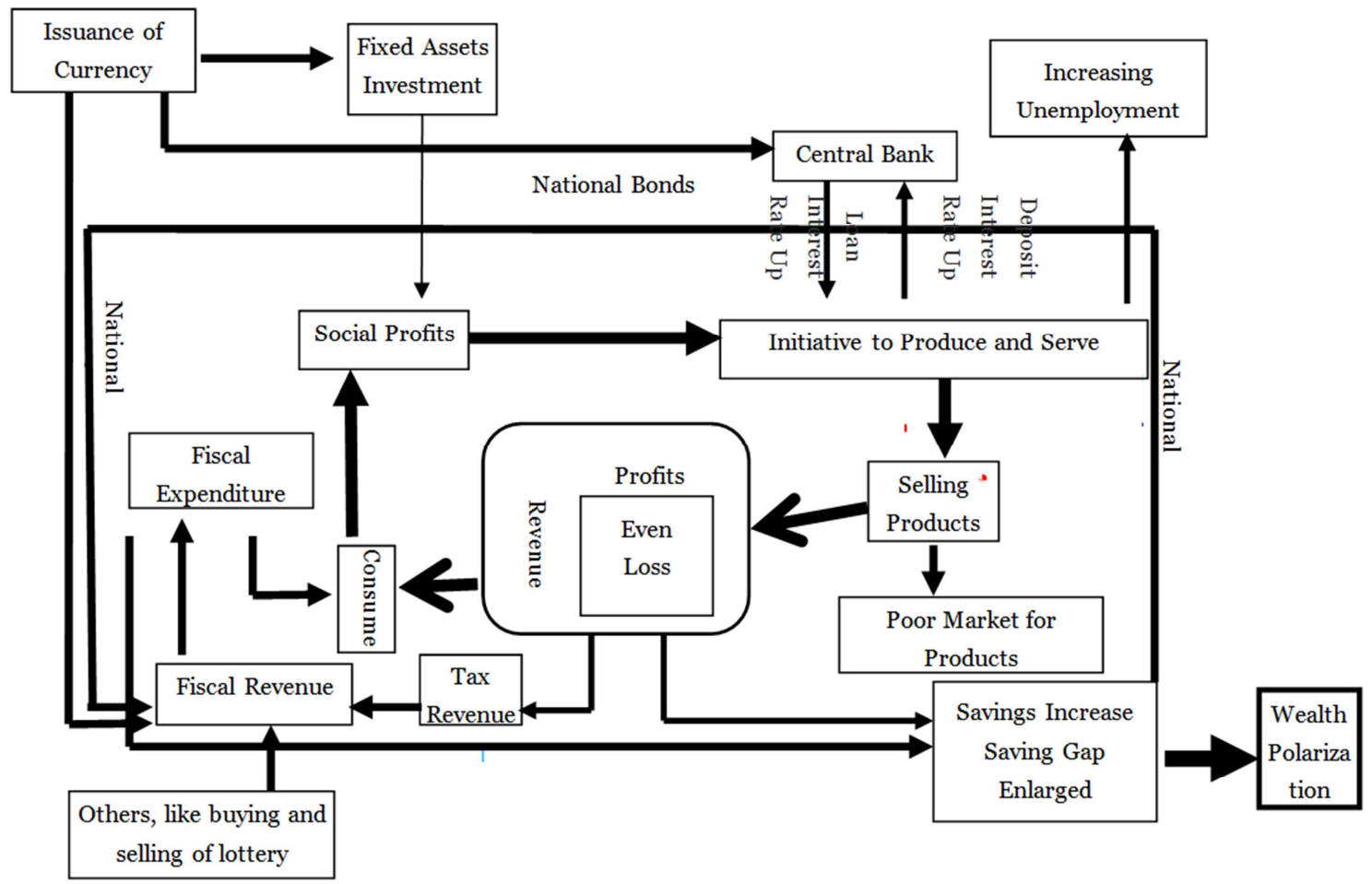

Figure 3. Unemployment.

\subsubsection{Definition of Unemployment}

Unemployment refers to the situation where a society fails to achieve a full employment for its members due to the failure of a commodity economy to make sufficient profits. In its essence, it is due to citizens' loss of equal borrowing power and fair chances for development that result in the profits that a commodity economy produce all flow into the pockets of the wealthy and powerful, who would prefer to save their money in banks, thus making the economy short of money for its normal operation and as a result, unemployment occurs.

\subsubsection{Wealth Polarization Is the Root Cause of Unemployment}

Wealth polarization of citizen is the root cause of unemployment.

Hypothesis 1: For simplicity, suppose that there are only three enterprises in a commodity economy, namely A, B and C, each having 4 Yuan. Each company has an entrepreneur, namely $\mathrm{A} 1, \mathrm{~B} 1, \mathrm{C} 1$, and two employees, which is remained unchanged. Further, suppose one piece of bread costs 1 Yuan, and at the beginning each employee has only 1 Yuan to produce bread, while their boss has two Yuan. Each one is assumed to consume one piece of bread. Meanwhile, suppose that the income proportion between $\mathrm{A}, \mathrm{B}$ and $\mathrm{C}$ is $1: 2: 3$, that between boss and employee is $1: 2$, or each entrepreneur has 2 Yuan while one employee has only 1 Yuan.

Result 1: The first time the nine people of the three enterprises consume 12 Yuan, and after the consumption A has $9 * 1 / 6+1$, or 2.5 Yuan, B has $9 * 2 / 6+1$, or 4 Yuan, and $\mathrm{C}$ has $9 * 3 / 6+1$, or 5.5 Yuan.

Hypothesis 2: Given a fixed interest rate, and ignoring the negative effects of inflation, suppose an input of 12 Yuan into the commodity economy to produce a total of 12 pieces of bread, which means the economy has 24 Yuan of currency, 12 pieces of bread with each one costing 2 Yuan.

Hypothesis 3: Suppose an input of 12 Yuan with 2 Yuan kept by A, 4 by $B$ and 6 by $C$ (with the same income proportion).

Result 2: A now has 4.5 Yuan, with its real purchasing power nearly half of its original funds. To minimize its loss, A has to fire one employee, and asks the remaining one to work more with less pay. B can manage to operate with a profit enough to cover its costs. Only $\mathrm{C}$ makes profits, for its revenue has included a large part of A's costs and investment. For the two workers in A, one is unemployed; the other has to work harder with less pay which cannot meet his basic needs, 
making him underemployed.

If the risks of inflation is to be reduced by increasing the interest rate, most of the input of 12 Yuan and the original 12 Yuan will end up in saving accounts, making it unlikely to produce 12 pieces of bread, and causing the workers of A to be unemployed or underemployed, who will have to live in worse conditions.

Conclusion: Result 1 and 2 show that in a commodity economy, there is room for large enterprises to annex small businesses due to the fact that completion always lead to amassing of wealth. Duringthe process, the larger businesses will continue to earn more wealth at the cost of the bankruptcy of the small ones, resulting in increasing unemployment. In short, wealth annexation leads to growing savings gap, which results in increase in unemployment.

\subsection{Wealth Polarization Leads to the Issuing of National Bonds}

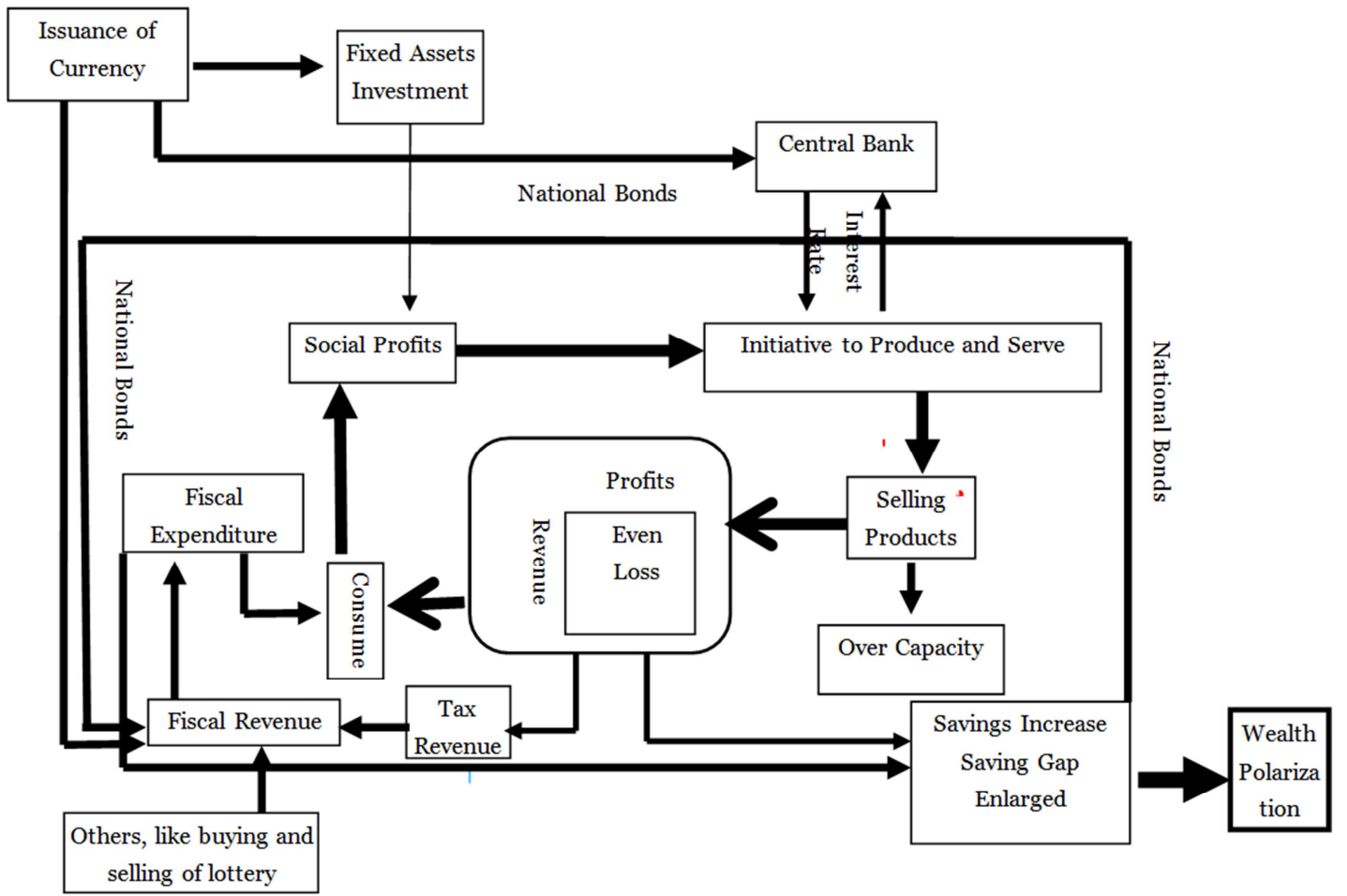

Figure 4. National Bonds.

\subsubsection{Definition of National Bonds}

A governmental bond is a bond issued by the government for borrowing from citizens, enterprises or other governments with a promise to pay periodic interest due to the fact that its tax revenue is not enough for government spending.

\subsubsection{National Bonds Are Not Reimbursable}

The government cannot issue currency to maintain its fiscal expenditure for fear of inflation, nor can it raise its tax for fear that unemployment might aggravate. In these cases, the government will have to borrow from the wealth that have savings in banks if it is creditworthy enough and promise to pay them interest. To repay its debt the government would spend its tax revenue and cut its fiscal expenditure. But even by cutting fiscal expenditure, a lot of countries still find it hard to cover their budget with their tax revenue, so by cutting expenditure alone is not enough to repay the debts.

\subsubsection{Wealth Polarization Is the Root Cause of Issuing of National Bonds}

As the volume of savings expands in the process of government's large-scale investment, the savings gap also widens, which directly leads to inflation and employment, two economic issues worrying the government.

Phenomenon 1. To relieve the impact of unemployment on the society, the government has to reduce its tax revenue so as to ensure enterprises can make basic profits to maintain the operation in the commodity economy. With the reduction of tax revenue, the government has to cut its fiscal spending. But the government has its employees' interests to consider, which make it unwilling to carry out mass layoff, nor to cut their pay, and as a result, the government will either issue currency to cover its budget, or borrow money from the citizens who have savings in banks and consider the government to be a creditworthy one who will pay them periodic interest payment.

Phenomenon 2. From the perspective of the current operation of a commodity economy, a government bond can both avoid the exacerbating of inflation and help a government to cover its spending.

Phenomenon 3. A bond takes the form of credential, which requires the government to pay back the money it borrows 
from the fortune controllers in accordance with the agreement in full. In other words, the national bonds in fact cause the savings of fortune controllers to grow, or fortune controllers' savings increase naturally thanks to the issuing of government bonds.

Conclusion: Phenomenon 1, 2 and 3 indicate that widening wealth polarization leads to unemployment and inflation. The government, in a bid to address these problems and cover its budget shortfalls, has to issue national bonds to cover its spending temporarily so as to maintain the normal operation of its economy. In short, wealth polarization directly leads to the increase in the issuing of national bonds, which in turn plunges the government into credit crisis.

\subsection{Other Impacts of Wealth Polarization}

Wealth polarization due to political power is the severest of its kinds. Power for life and family succession hereditary system severely deprive citizens of their freedom of production and life, of their power to have their voices heard, hinder the normal operation of the commodity economy, and worse, it would lead to the so-called purging movement, as is the case with China from Yu to the late Qing dynasty, Mao Zedong and Stalin periods, and North Korea, Cuba, Saudi Arabia, Syria and other states.

On the other hand, the wealth polarization due to economy tends to aggravate the antagonism in the society, bring about high crime rate, mobdom, drug, sex trade, human trafficking, human organ buying and selling, and result in ostentatious private affluence and lavish lifestyle on the part of the rich.

\section{Ideal Economic Operation Model}

\subsection{Basis on Which Ideal Economic Operation Model Proceeds}

The basis on which the ideal economic operation model proceeds is the key to solving the exacerbating wealth polarization due to growing savings.

The Figure below shows how an ideal economic model operates.

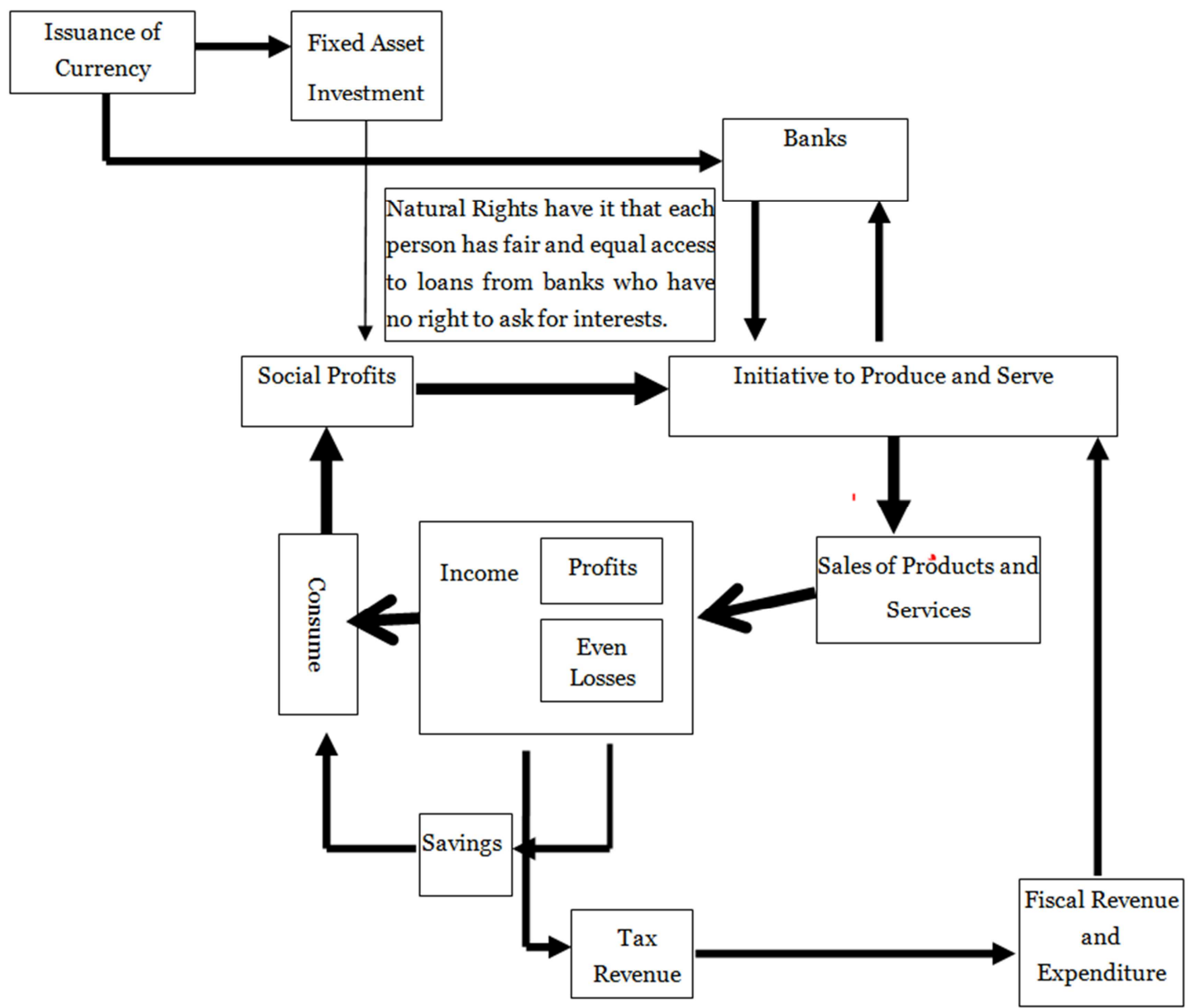

Figure 5. Ideal Economic Operation Model.

Qur'an 4:5 [11]: To those weak of understanding Make not over your property, which Allah hath made a means of support for you, but feed and clothe them therewith, and speak to them words of kindness and justice.

According to this teaching, property is for the maintenance of life, not for the amassing of wealth obtained by unfair means at the cost of others' interests. Further, the wealthy should return their riches amassed from the commodity economy back to the society, so as to facilitate the smooth operation of the economy and avoid increasing amassing of 
fortune.

\subsection{Key to Building the Ideal Economic Operation Model}

\subsubsection{Ideal Economic Operation Model is Based on Fair}

Qur'an (42.17) [12]: Allah has sent down Qur'an and fairness. But how can you know about that? Resurrection is drawing nearer.

This teaching reveals that an ideal economic model must be built on a fair basis. Wealth should be distributed fairly to sustain the operation of a commodity economy. Citizens should have the equal access to withdrawing cash from a bank, or the amount of loan a citizen can make is based on his identity so as to ensure his basic rights to life, and it follows that no bank has the right to ask for interests from citizens. When this is achieved, the currency in circulation in a commodity economy will not aggravate the wealth gap.

\subsubsection{Savings Are the Key Issue for the Ideal Economic Operation Model}

Qur'an (9:34) [9] preaches, "O ye who believe! there are indeed many among the priests and anchorites, who in Falsehood devour the substance of men and hinder (them) from the way of Allah. And there are those who bury gold and silver and spend it not in the way of Allah. announce unto them a most grievous penalty. Qur'an (9:35) [10]. On the Day when heat will be produced out of that (wealth) in the fire of Hell, and with it will be branded their foreheads, their flanks, and their backs, their flanks, and their backs.- "This is the (treasure) which ye buried for yourselves: taste ye, then, the (treasures) ye buried!

According to this teaching, constant savings is a highly harmful act.

Qur'an 30:8 [13]. Do they not reflect in their own minds?Not but for just ends and for a term appointed, did Allah create the heavens and the earth, and all between them: yet are there truly many among men who deny the meeting with their lord (at the Resurrection).

According to this teaching, everything is terminable. And the same is true of currency, a universal equivalent. In other words, when a government issue currency, it should at the same time see to it that the currency it has issued is terminable.

\section{Terminable Currency}

\subsection{Definition of Terminable Currency}

Terminable currency refers to a currency which is to circulate only for a given period of time, and its main feature is that it is terminable, rather than time-limitless. Endowing currency with this attribute will bring about a check on fortune amassers in their constant amassing of social fortune. In this sense, the terminable currency will force residents to stop the constant savings.

\subsection{Operational Mode of Terminable Currency of 10-year-duration}

The funds required by the society constitute the prerequisite for the circulation of capital. The terminable currency act as a universal equivalent by replacing the old currency with the new one, and the key for terminable currency to function normally in the process of currency conversion is to ensure that there is no violent fluctuation.

Based on this principle, the following replacement process is designed.

Hypothesis: Suppose a country has a population of 1 billion, and 5 trillion Yuan of assets, which needs currency of 5 trillion in circulation accordingly. To avoid sharp devaluation of currency, it is critical that the total money supply should not be more than 4 times of 5 trillion Yuan of assets. This means that the 1 billion labor force should not hold more than 20 trillion Yuan, or each one can only has less than 20 thousand Yuan.

\subsubsection{Enterprise's Capital Operation}

Condition 1: Suppose a firm determines its initial size of capital operation based on the size of its employees. Take Firm A having 100 employees for example. The 100 employees crate the Firm A in a joint investment, with its initiative size of capital reaching 2 million Yuan, or the 100 employees have access to 2 million Yuan of funds from the bank.

Condition 2: The bank, according to each one's credit limit, issues a total of 20 trillion to the 1 billion citizens.

Conditions 3: Within the 10 years, the government should not spend more than, say, 20 trillion.

Based on condition 2 and 3, after the 10 years, there will be 40 trillion of funds available in the society. On average, Firm A under condition 1 should have 4 million Yuan funds after the ten years, however, given the profit and loss, it should return back 3 million to the bank when the time comes for the replacement of old currency with the new one. If it fails to repay the 3 million, it will go bankruptcy, according to the bankruptcy system, which rules that the firm should repay part of its debt with its assets, and the outstanding debt shall be spread among all the employees. If after the ten years the 3 million is repaid, the firm will continue to operate, taking loans from the bank with a loan limit of 20 thousand per capita to start a new round of business.

The process is designed to ensure that the replacement of old currency with the new one is conducted smoothly, to assure that enterprises amassing too much wealth return their fortune once and for all to the society, and to increase people's ability to repay their debts.

\subsubsection{Individual Capital Operation}

A citizen is allowed to replace their funds up to 20 thousand Yuan at the most. Being non-member of the firm, citizens' capital can only be used as individual business funds. After ten years when the old currency is to be replaced by the new one, each citizen must return 30 thousand back to the bank. If they fail to do so, the bank has the right to deduct 20 thousand from the sum a citizen gets from the exchange of old and new currencies. By doing so the old currency still acts as a universal equivalent. On the other hand, after ten years if the citizen has more than 30 thousand Yuan of old currency, he, after paying the bank 30 thousand to get the 20 thousand Yuan of new currency, will have old currency left which he can 
spend on consumption. As a result, their consumption will create large amount of funds available for debtors who own the banks money, and who, with their ability to repay debts increases, will boost greatly the growth of the commodity economy.

\subsubsection{Further Collection of Old Currency}

Based on the above hypothesizes, each will pay the bank 30 thousand Yuan of old currency to get the new one, and at this rate, the society will have 10 trillion funds left after its 1 billion population pays back to the banks 30 trillion funds. So, the collection or dilution of this remaining funds will create a chance for each capable of creating fortune to exchange currency at a rate of 10: 1. In other words, after the first round of exchange of currency, people can use their remaining old currency to buy the new one at a rate of 10: 1 , which is the approach taken by the banks to collect the old currency.

\subsubsection{Cost of Currency}

Bank, as a financing institution, should be independent from organs of authority, for it is responsible for the issue of currency and its collection. Bank must consist of three independent and mutually restrictive institutions, and its function mainly include the issue of currency based on the size of population, the formulation of monetary policies on the basis of equality concerning the issue and collection of money, the printing or coining of banknotes, and monetary judicial oversight. The tax revenue and the profits of public investments make up the main funds to cover the costs of printing or coining of banknotes and government spending.

The above illustrates briefly how terminable currency goes into circulation and comes back to bank through collection.

\section{Findings and Value}

\subsection{Conclusion}

Conclusion 1: Currency goes into the commodity economy through government' investment in fixed assets and government spending, and then becomes household's income, which then is saved in the banks. Meanwhile, due to unequal income model and unequal access to loans, the savings gap widens in modern society.

Conclusion 2: What drives people to save is the limitless validity of currency acting as a universal equivalent. Therefore it is critical for the policies to be effective in checking people's constant saving behavior which has resulted in the flowing of currency out from the economy, with a mechanism for limiting the duration of currency's function as universal equivalent. That is, when the terms end for the old currency, there will be new currency in place to take its place. In addition, the amount by which people can exchange the two currencies is limited, or within the amount of total wealth of a society divided by the number of its population. As a rule, monetary policy should be made to prevent the worsening wealth polarization due to increasing size of saving, and further avoid social chaos arising from economic issues and social problems.

\subsection{Value}

This paper is based on the principles of Qur'an, which takes fairness as the sole basis of politics and society. Also, according to the teaching of Qur'an which totally opposes saving, this paper designs an operational mode of commodity economy in which producers, in an effort to maximize profits, produce, sell, make profits, and consume with currency as the universal equivalent. Further, it develops a new idea of terminable currency, which is expected to solve the issue of wealth polarization, the root cause of all economic problems. Finally, it indicates that only by resorting to social contracts to solve the problem of wealth polarization, will an ideal and sound commodity economy be built, so will an ideal society.

\section{References}

[1] Peng Mengxia \& Dong Bingnan (2012). Study on the Relationship between the Rural Residents Savings Rate and the Income Gap between Urban and Uural Areas in China: An Empirical Analysis Based on Chinese Data 1985-2010 [J]. Contemporary Economics, vol. 15, pp. 76-77.

[2] Jin Ye, Li Hongbin and Wu Binzhen (2011). The income Gap and Social Status Exploration: A Cause of High Saving Rate [J] Economics (quarterly), vol. 3, pp. 887-912.

[3] Yang Miaoshu \& Tan Huaqing (2011). An Aging Population, Family Structure and Savings Rate: in the Context of Serious Urban-rural Income Gap [J]. Entrepreneurial Studies, vol. 8, pp. 137-138.

[4] Wang Xiaolu (2007). Serious Income Gap: Internal Cause of Insufficient savings and Excess Consumption. China Opening Herald, vol. 5, pp. 34-36.

[5] Yang Xufei (2009). Research on the Influence Factors of Bank Deposits in China: Saving Effect Analysis Arising from Income Gap [J]. Journal of Graduate Students of Zhongnan University of Economics and Law, vol. 6, pp. 62-69.

[6] Cheng Ying (2007). Discuss on the Relationship between High Savings Rate and the Gap of Income Distribution [J]. China Price, vol. 11, pp. 51-53.

[7] Han Xiaoyan (2010). Research the Relationship between High Saving Rate and Widening Urban-rural Income Gap [J]. Management Supervisors, vol. 22, pp. 2, 9.

[8] Song Yunxing (2015). Income Gap and Saving: Analysis Based on OECD National Panel Data. Financial Theory \& Practice, vol. 12 , pp. 8-11.

[9] The English Version of The Gamoos Qur'an. Qur'an 9:34.

[10] The English Version of The Gamoos Qur'an. Qur'an 9:35.

[11] The English Version of The Gamoos Qur'an. Qur'an 4:5.

[12] The English Version of The Gamoos Qur'an. Qur'an 42.17.

[13] The English Version of The Gamoos Qur'an. Qur'an 30:8. 